\title{
Identification of SNPs in candidate genes related to water stress in Eucalyptus
}

\author{
Cíntia Helena Duarte Sagawa ${ }^{{ }^{*},}$, Leonardo Curi Martin ${ }^{1}$, Andréia Santoro1, Julio Cezar Santos Otto1, \\ Juliana Erika de Carvalho Teixeira ${ }^{2}$, Rinal do César de Paula ${ }^{3}$, Celso Luis Marino ${ }^{1}$ \\ From IUFRO Tree Biotechnology Conference 2011: From Genomes to Integration and Delivery \\ Arraial d'Ajuda, Bahia, Brazil. 26 June - 2 July 2011
}

\section{Background}

Forestry companies have occupied Northern and Northeastern of Brazil with plantations of Eucalyptus species; however, limitations on water supply are affecting the biomass production and reducing the yield significantly [1].Tolerant plants develop defense mechanisms like hormone production of abscisic acid (ABA) and osmoprotector glycine betain (GB) when submitted to drought conditions [2]. Identifying and studying genomic regions related to water stress tolerance are important for tree improvement programs. In this work, SNPs in candidate genes, 9-cis-epoxy-carotenoid dioxygenase (NCED) and choline monooxygenase (CMO), of ABA and GB biosynthetic pathways related to drought tolerance in a population of Eucalyptus were identified, as well as, a possible molecular marker associated to genomic regions related to plant response to water stress through AFLP technique [3] combined with bulk segregant analysis method [4].

\section{Materials and methods}

Contrasting plants of E. grandis, E. urophylla, and their hybrids were selected according to their physiology. Specific primers were designed from homology sequences from Eucalyptus ESTs databank and amplification products submitted to sequencing which allowed the identification of SNPs and the genotyping of these plants. For the identification of the AFLP marker, contrasting DNA bulks were digested with restriction enzymes combination and routine protocols were followed. The selective amplification products were separated on $6 \%$ denaturing polyacrylamide gel and seen in the silver nitrate staining [5].

\footnotetext{
* Correspondence: cintiasagawa@ibb.unesp.br

'Departamento de Genética, UNESP, Botucatu, São Paulo, 18618-970, Brazil Full list of author information is available at the end of the article
}

\section{Results and conclusions}

Seven SNPs were identified in a region of 1230 bp on NCED gene from which five were in codified regions and generated synonymous mutations. For the CMO gene, 49 SNP were identified in a region of $3885 \mathrm{bp}$, which 12 were in codified regions and 37 in UTRs and intron regions. Especially for these codified regions; $83,3 \%$ of the mutations were synonymous and $16,7 \%$ were non-synonymous. Through the genotyping of the SNPs, the NCED and CMO genes presented respectively, seven haplotypes with 15 different genotypes and 18 haplotypes with 16 diverse combinations. Nevertheless, CMO gene showed some unique genotypes for some species. Then, the genotyping of individuals by the allele-specific extension technique demonstrated to be efficient; moreover the SNPs primers designed can decrease costs and permit the genotyping of these mutations in large scale of contrasting populations to water deficit and in population studies. From the analysis of the DNA bulks, 50 AFLP primer combinations were tested from which 27 generated polymorphic bands between the bulks and just one primer combination was confirmed in all susceptible plants of the bulk by now. This fragment sequence will be compared and converted into PCR-based markers.

\section{Author details \\ 'Departamento de Genética, UNESP, Botucatu, São Paulo, 18618-970, Brazil. ²FIBRIA, São Paulo, 12340-010, Brazil. ³Departamento de Produção Vegetal, UNESP, Jaboticabal, São Paulo, 14884-900, Brazil.}

Published: 13 September 2011

\section{References}

1. Whitehead D, Beadle CL: Physiological regulation of productivity and water use in Eucalyptus: a review. For Ecol Manag 2004, 193:113-140. 
2. Chen THH, Murata N: Enhancement of tolerance of abiotic stress by metabolic engineering of betaines and other compatible solutes. Curr Opin Plant Biol 2002, 5:250-257.

3. Vos P, Hogers R, Bleeker M, Reijans M, Van de Lee T, Hornes M, Frijters A, Pot J, Peleman J, Kuiper M, Zabeau M: AFLP: a new technique for DNA fingerprinting. Nucleic Acids Res 1995, 23:4407-4414.

4. Michelmore RW, Paran I, Kesseli RV: Identification of markers linked to disease-resistance genes by bulked segregant analysis: A rapid method to detect markers in specific genomic regions by using segregating populations. Proc. Natl. Acad. Sci. USA 1991, 88:9828-9832.

5. Creste $S$, Tulmann Neto A, Figueira A: Detection of single sequence repeat polymorphisms in denaturing polyacrylamide sequencing gels by silver staining. Plant Mol Biol Rep 2001, 19:299-306.

doi:10.1186/1753-6561-5-S7-P52

Cite this article as: Duarte Sagawa et al.: Identification of SNPs in candidate genes related to water stress in Eucalyptus. BMC Proceedings 2011 5(Suppl 7):P52.

\section{Submit your next manuscript to BioMed Central} and take full advantage of:

- Convenient online submission

- Thorough peer review

- No space constraints or color figure charges

- Immediate publication on acceptance

- Inclusion in PubMed, CAS, Scopus and Google Scholar

- Research which is freely available for redistribution

Submit your manuscript at www.biomedcentral.com/submit 